\title{
Early season grazing by cattle of tall larkspur- (Delphinium spp.) infested rangeland
}

\author{
JAMES A. PFISTER, MICHAEL H. RALPHS, GARY D. MANNERS, DALE R. GARDNER, KERMIT W. PRICE, \\ AND LYNN F. JAMES
}

Authors are with the USDA-ARS Poisonous Plant Research Laboratory, Logan, Ut. 84341 (Pfister, Ralphs, Gardner, Price, and James); Manners is with the USDA-ARS Western Regional Research Laboratory, Albany, Calif. 94710.

Abstract

A series of summer grazing studies were conducted to evaluate cattle consumption of preflowering tall larkspur (Delphinium barbeyi [Huth] or $D$. occidentale [Wats.] Wats.) on mountain rangeland in Utah, Colorado, and Idaho during 1987 to 1995. Cattle ate little or no larkspur before flowering racemes were elongated. Consumption of tall larkspur by cattle was also generally low during the early flower stage, with some notable exceptions at the Salina and Manti, Utah sites. These graxing studies indicate that risk of losing cattle to tall larkspur is low if plants have not flowered. Even though concentration of toxic alkaloids is typically much higher in immature compared to mature tall larkspur, toxicosis is unlikely to occur because consumption by cattle is low. Many livestock operations can gain 4 to 5 weeks of low-risk grazing on tall larkspur-infested rangeland early in the grazing season, and this should be considered in developing grazing management plans.

Key Words: grazing management, poisonous plants, alkaloids, methyllycaconitine, cattle diets

Tall larkspur (Delphinium barbeyi [Huth] or D. occidentale [Wats.] Wats.) toxicity is a severe problem for cattle grazing western mountain ranges. Cattle death losses from tall larkspur average $5 \%$ and may exceed $15 \%$ annually in areas where the plant is abundant (J.A. Pfister, personal observations); losses to tall larkspur cost cattle producers millions of dollars annually (Nielsen and Ralphs 1988). Tall larkspur infestations often dictate summer grazing management of cattle on mountain rangelands. Significant amounts of forage are ungrazed each year on these highly productive ranges because many producers defer grazing of tall larkspur-infested pastures until late summer or early fall when tall larkspur declines in toxicity (Ralphs et al. 1988, Pfister et al. 1994a). Other producers avoid grazing infested pastures with cattle entirely, or substitute sheep grazing for cattle, reason-

\footnotetext{
We thank the numerous Forest Service personnel and permittees who graciously assisted us in conducting research on the grazing allotments; we thank Dr. Nancy Peterson, Connie Clementson, Floyd Reed, Brent Bunderson, Tracy Weber, and Lynn Kitchen for assistance with several grazing studies. All experimental protocols and procedures were approved by the Utah State University IACUC, and were conducted under veterinary supervision.

Manuscript accepted 5 Oct. 1996
}

Resúmen

Desde 1987 y hasta 1995 se condujeron una serie de estudios a pastoreo de verano con el objeto de evaluar el consumo de larkspur alto (Delphinium barbeyi [Huth] o D. occidentale [Wats.] Wats.) en prefloración por partede bovinos en pasturas naturales de montaña distribuidas en Utah, Colorado, y Idaho. Antes de la elongación de los racimos de floración, los vacunos consumieron poco o nada de larkspur alto. El consumo de larkspur alto por parte del ganado vacuno también resulto bajo durante el estadio de floración temprana, con algunas notables excepciones en Salina y Manti, sitios de Utah. Los presentes estudios a pastoreo indican que el riesgo de perder vacunos por consumo de larkspur alto es bajo si las plantas no han florecido. Aunque la concentración de alcaloides tóxicos en larkspur alto es tipicamente mucho mayor en plantas inmaduras que en plantas maduras, es improbable la ocurrencia de intoxicación debido a que el consumo por parte de vacunos es bajo. Temprano en la estacion de pastores, muchas explotaciones de ganadería pueden ganar de 4 a 5 semanas de pastoreo con bajo riesgo de intoxicación en pasturas naturales infestadas por larkspur alto. Esto debiera ser considerado para el desarrollo de planes de manejo del pastoreo.

ing that the risk of cattle poisoning is not worth the grazing benefits. These adjustments have caused some ranches to relinquish their cattle grazing permits and leases on public lands, resulting in diminished ranch values.

The primary toxins in tall larkspur are the diterpenoid alkaloids, methyllycaconitine (MLA) and 14-deacetylnudicauline (DAN) (Manners et al. 1995). These toxins reversibly bind to acetylcholine receptors (Drasdo et al. 1992) at the neuromuscular junction, causing muscular fatigue, paralysis, and eventually death from respiratory paralysis. Lethality of a tall larkspur dose is determined by several factors, including concentration of toxic alkaloids in the plant, amount eaten, rate of consumption, and susceptibility of individual animals.

As tall larkspur matures, toxicity (i.e., concentration of toxic alkaloids) typically decreases (Ralphs et al. 1988, Pfister et al. 1994a). Previous grazing studies have found that cattle consumption appears to begin during the flower stage, and peak during late flower or pod stage (Pfister et al. 1988a, 1988b); the congruence of declining, but still substantial, plant toxicity with increas- 
ing plant palatability appeared to form a toxic window of risk during which many cattle deaths could be predicted (Pfister et al. 1988a). Our objective in this series of grazing studies was to determine when cattle graze tall larkspur in relation to plant phenology and toxicity, with specific emphasis on early flowering, i.e., transition between preflowering and full flowering. Our hypothesis was that cattle would eat no tall larkspur before elongation of flowering racemes. Consequently, risk associated with grazing tall larkspur-infested ranges before flowering may be low even though immature tall larkspur may be very toxic.

\section{Methods}

\section{General}

We defined early season grazing as grazing before tall larkspur elongated flowering racemes. Growth of tall larkspur is influenced by environmental conditions (e.g., snow cover, temperature, precipitation), but general patterns are apparent. Newly emergent tall larkspur shoots grow for several weeks in the vegetative stage. Visible bud clusters then develop for about 2 or 3 weeks, followed by rapid elongation of flowering racemes. Flowers on newly-elongated racemes generally require one to several weeks to open fully after stems have reached about $90 \%$ of their mature height. We designated the period before raceme elongation as the preflower stage, and the period after raceme elongation but before full flower opening as the early flower stage. In each trial, phenological stage was determined by the stage of growth of the majority of larkspur plants growing within the study pasture. Several hundred tall larkspur plants within each study area were visually examined on a daily basis, and dominant phenological stage was determined.

All pastures used in these trials were on National Forest land and enclosed with an electric fence. Grazing pressure in all trials was light to moderate. Daily bite counts were used to determine animal diets (Pfister et al. 1988a, 1988b; Pfister and Manners 1991). Beginning at about 0630 hours, individual animals were focally sampled (Altmann 1974) in a predetermined random order. Each animal was observed in turn for 5 minutes. After all animals had been observed, the process was repeated during all active grazing periods until about 1900 hours, when cattle were generally placed in a corral for the night. Bites were categorized as grasses, shrubs, other forbs, and larkspur bud, flower, leaf, or leaf and stem. We defined an individual bite as a single cropping motion, always indicated by a head jerk, often accompanied by a visible sweep of the tongue, and independent of chewing motions.

The trials reported herein that were conducted from 1987 to 1991 constitute a reanalysis of data from control animals in previously published studies (Table 1). Trials from 1993 to 1995 report new data. Bite count methodology and manner of assessing larkspur phenology were the same for all trials.

Larkspur leaves and reproductive parts (i.e., bud, flower) were collected periodically for alkaloid analysis. Fresh plant material was harvested from at least 20 plants, composited, and frozen at $-20^{\circ} \mathrm{C}$. In Montrose, Colo. during 1995, individual plant samples were collected by harvesting all leaves from 20 randomly selected stems from 20 different plants, as recommended by Manners and Pfister (1996). Samples were freeze-dried and ground through a Wiley mill to pass through a $1-\mathrm{mm}$ screen. Plant material was extracted and analyzed for methyllycaconitine (MLA) and 14-deacetylnudicauline (14-DAN) by high performance liquid chromatography (HPLC) methods (Manners and Pfister 1993). Since these 2 alkaloids account for $>80 \%$ of the toxicity of tall larkspur (Manners et al. 1993), and have a similar $\mathrm{LD}_{50}$ in mice (4.0 to $4.5 \mathrm{mg} / \mathrm{kg} \mathrm{BW}$; K.E. Panter, personal communication), we summed their concentrations and expressed the sum as total toxic alkaloid (TTA) concentration (mg/g, dry wt basis). Typically, MLA constitutes $\geq 90 \%$ of the toxic alkaloid concentration (G.D. Manners, unpublished data).

Standing crop ( $\mathrm{kg} / \mathrm{ha}$ ) was determined near the beginning of each trial by clipping $\geq 20,0.25-\mathrm{m}^{2}$ plots to a $1-\mathrm{cm}$ stubble height. Clipped material was separated into tall larkspur, grass, and other forbs, dried in a forced air oven at $60^{\circ} \mathrm{C}$ for 48 hours, and weighed. In all trials, other forages besides tall larkspur were abundant in the pastures (Table 1).

Table 1. Characteristics of each grazing study, including a literature reference if the data were extracted and reanalyzed from a previously published data set

\begin{tabular}{|c|c|c|c|c|c|c|}
\hline Trial \# & Location & Year & Larkspur spp. & $\begin{array}{l}\text { Total non-toxic } \\
\text { standing crop }\end{array}$ & $\begin{array}{c}\text { Larkspur } \\
\text { standing crop }\end{array}$ & Reference $^{b}$ \\
\hline & & & & $(\mathrm{kg} / \mathrm{ha})^{\mathrm{a}}$ & $(\mathrm{kg} / \mathrm{ha})$ & \\
\hline 1 & Manti, Utah & 1987 & D. barbeyi & 794 & 165 & Pfister et al. 1988a \\
\hline 2 & Oakley, Idaho & 1988 & D. occidentale & 692 & 731 & Pfister and Manners 1991 \\
\hline 3 & Yampa, Colorado & 1990 & D. barbeyi & 1380 & 591 & Pfister and Manners 1995 \\
\hline 6 & Yampa, Colorado & 1994 & D. barbeyi & 1112 & 524 & \\
\hline 7 & Salina, Utah ${ }^{c}$ & 1994 & $\begin{array}{l}\text { D. barbeyi and } \\
\text { D. occidentale }\end{array}$ & $\ldots$ & --- & \\
\hline 8 & Salina, Utah & 1995 & $\begin{array}{l}\text { D. barbeyi and } \\
\text { D. occidentale }\end{array}$ & 538 & 440 & \\
\hline 9 & Montrose, Colorado & 1995 & D. barbeyi & 646 & 212 & \\
\hline
\end{tabular}

${ }_{3}$ Availability when the grazing trial began; total standing crop excludes tall larkspur; grazing pressure in all trials was light to moderate

Data from previously published studies includes only control animals from experiments in which various treatments were applied

This trial ended prematurely when all the experimental cattle escaped from the pasture

This population of tall larkspur was a mix of $D$. barbey $i$ and $D$. occidentale and hybridized crosses 


\section{Trial 1: Manti, Utah 1987}

Five yearling Hereford heifers $(318 \mathrm{~kg})$ grazed a 3-ha pasture at the head of Six Mile Canyon, $25 \mathrm{~km}$ east of Manti, Ut., at 3,250 $\mathrm{m}$ elevation (Pfister et al. 1988a). These heifers were familiar with tall larkspur as they had grazed this area as calves the previous summer. Observations were made during the preflower stage ( 2 to $11 \mathrm{July}$ ) and during the early flower stage ( 20 to $30 \mathrm{July}$ ). Major plant species were tall larkspur (Delphinium barbeyi), currant (Ribes montigenium McClatchie), slender wheatgrass (Elymus trachycaulus [Link] Gould ex Shinners), mountain brome (Bromus carinatus H. \& A.), and sagewort (Artemisia ludoviciana var. incompta [Nutt.] Cronq.).

\section{Trial 2: Oakley, Idaho 1988}

Four yearling Hereford heifers $(267 \mathrm{~kg}$ ) grazed a 3-ha pasture $30 \mathrm{~km}$ west of Oakley, Ida. at 2,300 m elevation (Pfister and Manners 1991). These heifers grazed on mountain range as calves, but exposure to tall larkspur was unknown. Observations were made during the preflower stage (June 15 to 24 ) and during early flower (June 29 to July 8). Major plant species were tall larkspur (Delphinium occidentale [Wats.] Wats.), snowberry (Symphoricarpos oreophilus Gray), Great Basin wildrye (Elymus cinereus Scribn. \& Merr.), slender wheatgrass, and Idaho fescue (Festuca idahoenis L.).

\section{Trial 3: Yampa, Colorado 1990}

Four Hereford X Angus X Charolois yearling heifers (286 kg) were grazed during the preflower stage (21 to 30 June) and the early flower stage ( 1 to 10 July). The trial was conducted near Dunkley Pass, $25 \mathrm{~km}$ west of Yampa, Colo. at an elevation of 2,650 m (Pfister and Manners 1995). These heifers grazed this allotment the previous summer. Dominant plants were tall larkspur (Delphinium barbeyi), false hellebore (Veratrum californicum Durand), cow parsnip (Heracleum lanatum Michx.), meadowrue (Thalictrum fendleri Engelm. ex Gray), sweet cicely (Osmorhiza occidentalis [Nutt.] Torr.), snowberry, and mountain brome.

\section{Trial 4: Yampa, Colorado 1991}

This grazing site was the same as used in Trial 3, and 2-yr old heifers (same animals as used in Trial 3; $372 \mathrm{~kg}$ ) were grazed during the preflower stage (26 June to 5 July), and during the early flower stage (6 to 18 July) (Pfister and Manners 1995).

\section{Trial 5: Yampa, Colorado 1993}

Five, 2-yr old Hereford X Angus heifers ( $375 \mathrm{~kg}$ ) grazed a 4-ha pasture on a site about $0.5 \mathrm{~km}$ from that used during Trials 3 and 4; site characteristics and vegetation were similar. These cattle had previously grazed a summer mountain range in Utah, but were naive to this allotment. Cattle grazed during the preflower stage (June 18 to July 5) and during the early flower stage (July 6 to 20 ).

\section{Trial 6: Yampa, Colorado 1994}

Five, 3-year old cows (same animals as used during Trial 5; $487 \mathrm{~kg}$ ) grazed during the preflower stage ( 9 to 21 June) and during the early flower stage ( 22 June to 5 July) on a site adjacent and similar to that used during Trial 5.

\section{Trial 7: Salina, Utah 1994}

Five yearling heifers $(300 \mathrm{~kg})$ grazed a 4-ha site dominated by a mixed tall larkspur population (mostly $D$. barbeyi with some $D$. occidentale and hybrid crosses). Other major plant species were snowberry, mountain brome, meadowrue, and currant. Heifers had previous grazing experience on tall larkspur-infested rangeland about $35 \mathrm{~km}$ from this site. Cattle grazed during the preflower stage (18 to 30 June) and during the early flower stage (July 1 to 7). The pasture was located near the Salina Reservoir in the Fishlake National Forest about $40 \mathrm{~km}$ from Salina, Ut., at an elevation of $2,950 \mathrm{~m}$.

\section{Trial 8: Montrose, Colorado 1995}

Five, 4-year old cows $(574 \mathrm{~kg}$ ) with previous experience grazing tall larkspur-infested rangeland in Utah were grazed during the preflower stage (5 July to 30 July) and early flower stages (1 to 12 Aug.). The 4-ha pasture was situated at $2,850 \mathrm{~m}$ elevation on the Umcompahgre Plateau about $38 \mathrm{~km}$ southwest of Montrose, Colo. Dominant plants under the aspen (Populus tremuloides) Michx.) canopy were tall larkspur (Delphinium barbeyi), low larkspur (Delphinium nuttallianum Pritz.), lovage (Ligusticum porteri Coult. \& Rose), meadowrue, currant, and mountain brome.

\section{Trial 9: Salina, Utah 1995}

Five, 3- and 4-yr old cows ( $499 \mathrm{~kg}$ ) with previous experience grazing tall larkspur-infested rangelands grazed a 5-ha pasture during the preflower stage (6 to 21 to July 6 Aug.) and during the early flower stage (22 July to 6 Aug.). The pasture was located at the same site as used during Trial 7.

\section{Statistical analysis}

Each trial was analyzed separately for the dependent variable percent of bites of tall larkspur. In the general linear model (SAS 1988), animals were considered as blocks, and periods as treatments. The model also included the animal $\times$ period interaction, days nested within periods, and animal $X$ day within period as the residual error term. The animal $\times$ period interaction was first tested for significance. If the animal $X$ period term was significant $(P<0.05)$, then the animal $X$ period interaction was used to test for period differences; if this interaction was not significant, then the residual error term was used to test for period differences.

\section{Relating Plant Toxicity and Consumption}

The relationship between tall larkspur toxicity (i.e., toxic alkaloid concentration, $\mathrm{mg} / \mathrm{g}$ ) and consumption (\% of diet as tall larkspur) was determined by calculating the amount of tall larkspur an animal would have to eat as a percentage of daily dry matter intake for toxicosis to occur (dose response) over a range of toxic alkaloid concentrations in tall larkspur. In all calculations we assumed a body weight of $600 \mathrm{~kg}$ and dry matter intake at 100 $\mathrm{g} / \mathrm{BW}_{\mathrm{kg}}{ }^{75}$ (Cordova ct al. 1978). We uscd 2 doses of TTA: 1) 21 $\mathrm{mg} / \mathrm{kg}$ BW as a dose likely to cause overt clinical signs (muscular weakness, temporary sternal recumbency, and perhaps fatal bloat); and 2) $40 \mathrm{mg} / \mathrm{kg} \mathrm{BW}$ as a plausible, but untested $\mathrm{LD}_{50}$ in cattle. Originally we reported that an effective dose of TTA was $11 \mathrm{mg} / \mathrm{kg}$ (Pfister et al. 1994b), but recalibration and reanalysis of the same plant material by HPLC has established the correct effective dose in cattle to be $21 \mathrm{mg} / \mathrm{kg}$ body weight. We catego- 
rized dose, and the resultant likelihood of poisoning, in each grazing trial as either high, medium, or low. The relative risk of losing cattle is primarily related to the amount of tall larkspur ingested, and understanding the relationship between plant toxicity and amount consumed can provide an indication of how risky a particular grazing situation may be.

\section{Results}

\section{Trail 1. Manti, Utah 1987}

Cattle ate no tall larkspur during the preflower stage, whereas total larkspur consumption increased $(\mathrm{P}<0.05)$ during the early flower stage, and averaged 7\% of bites (Table 2). The majority of the larkspur consumed during the early flower stage was flowers (5.7\%). On the ninth day of the early flower period, cattle averaged $32 \%$ of bites as larkspur. One animal ate about $50 \%$ of her diet (Table 2) as flowers on day 9 . She was probably approaching an intoxicating threshold (Pfister et al. 1997), but did not show clinical signs, presumably because tall larkspur was ingested gradually over an entire day and flowers were low in TTA concentration. Leaves were relatively high in toxic alkaloids $(>7$ $\mathrm{mg} / \mathrm{g}$ ) early in the grazing season, and maintained relatively high concentrations ( $>5 \mathrm{mg} / \mathrm{g}$ ) after elongation of flowering stems (Fig. 1). The ingested larkspur dose, hence risk, was nonexistent during the preflower stage, because cattle ate no larkspur. The larkspur dose was low to medium during the early flower stage (Fig. 2), when maximal leaf consumption of about 19\% (Table 2) in conjunction with leaf toxicity resulted in a potentially dangerous situation. Nonetheless, cattle showed no clinical signs of intoxication. Even though cattle ate a substantial amount of tall larkspur flowers on day 9 in the early flower stage, intoxication did not occur (Fig. 2) because flower toxicity was low.

\section{Trial 2. Oakley, Idaho 1988}

Cattle selected only a few bites of tall larkspur during the preflower stage; although consumption increased $(P<0.05)$ during the early flower stage, it remained very low (Table 2 ). Most $(>90 \%$ ) of the larkspur eaten during the early flower stage was leaf material. The concentration of TTA was relatively high $(\geq 6.5 \mathrm{mg} / \mathrm{g})$ in leaves and buds early in the growing season, but declined with maturity (Fig. 1). Although TTA concentration remained relatively high during 2 periods, the ingested toxic alkaloid dose (Fig.2), and the risk of losing cattle, remained low because consumption was low.

\section{Trial 3. Yampa, Colo. 1990}

Cattle ate no tall larkspur during either the preflower or early flower stage. The concentration of TTA was high in immature leaves, but declined to relatively low concentrations when larkspur elongated flowering racemes (Fig. 1). Buds and flowers initially contained a high concentration of TTA, and although concentration declined with maturity, TTA concentration remained relatively high when larkspur began to flower. The risk of losing cattle was essentially zero during both grazing periods because cattle ate no tall larkspur.

\section{Trial 4. Yampa, Colo. 1991}

Cattle ate a small number of leaves ( $<0.1 \%$ of bites) during both the preflower and early flower stages ( $P>0.05$; Table 2 ).
Table 2. Mean daily consumption of tall larkspur plant parts ( $\%$ of bites ( \pm SE) by cattle during the preflower and early flower stages of growth, and maximum amount of larkspur consumed by any individual animal on any day during each grazing period

\begin{tabular}{|c|c|c|c|c|c|c|}
\hline \multirow[b]{3}{*}{ Trial/Plant part } & \multicolumn{6}{|c|}{ Larkspur Growth Stage } \\
\hline & \multicolumn{3}{|c|}{ Preflower } & \multicolumn{3}{|c|}{ Early Flower } \\
\hline & \multicolumn{2}{|c|}{ Mean (SE) } & \multirow{2}{*}{ Maximum } & \multicolumn{2}{|c|}{ Mean(SE) } & Maximum \\
\hline & $\ldots$ & $\cdots$ & & es) - - & $\cdots$ & $\ldots \ldots$ \\
\hline \multicolumn{7}{|l|}{$\begin{array}{l}\# 1 \\
\text { Manti, UT } 1987\end{array}$} \\
\hline Leaf & 0.0 & $(0.0)$ & 0.0 & 0.9 & $(0.4)$ & 19.2 \\
\hline Bud & 0.0 & $(0.0)$ & 0.0 & 0.0 & $(0.0)$ & 0.0 \\
\hline Flower & 0.0 & $(0.0)$ & 0.0 & 5.7 & (1.5) & 50.8 \\
\hline Total & 0.0 & $(0.0)$ & 0.0 & 6.7 & (1.6) & 50.8 \\
\hline \multirow{2}{*}{\multicolumn{7}{|c|}{$\begin{array}{l}\# 2 \\
\text { Oakley, ID } 1988\end{array}$}} \\
\hline \multicolumn{6}{|l|}{ Oakley, ID 1988} & \\
\hline Leaf & 0.1 & $(0.08)$ & 2.0 & 0.6 & $(0.2)$ & 4.1 \\
\hline Bud & 0.0 & $(0.0)$ & 0.0 & 0.0 & $(0.0)$ & 0.0 \\
\hline Flower & 0.0 & $(0.0)$ & 0.0 & 0.1 & $(0.04)$ & 1.5 \\
\hline Total & 0.1 & $(0.08)$ & 2.0 & 0.7 & $(0.2)$ & 4.1 \\
\hline \multicolumn{7}{|l|}{$\# 3$} \\
\hline \multicolumn{7}{|c|}{ Yampa, CO 1990} \\
\hline Leaf & 0.0 & $(0.0)$ & 0.0 & 0.0 & $(0.0)$ & 0.0 \\
\hline Bud & 0.0 & $(0.0)$ & 0.0 & 0.0 & $(0.0)$ & 0.0 \\
\hline Flower & 0.0 & $(0.0)$ & 0.0 & 0.0 & $(0.0)$ & 0.0 \\
\hline Total & 0.0 & $(0.0)$ & 0.0 & 0.0 & $(0.0)$ & 0.0 \\
\hline \multicolumn{7}{|l|}{ \#4 } \\
\hline \multicolumn{7}{|c|}{ Yampa, CO 1991} \\
\hline Leaf & 0.03 & $(0.02)$ & 0.4 & 0.1 & $(0.03)$ & 2.5 \\
\hline Bud & 0.0 & $(0.0)$ & 0.0 & 0.0 & $(0.0)$ & 0.0 \\
\hline Flower & 0.0 & $(0.0)$ & 0.0 & 0.0 & $(0.0)$ & 0.0 \\
\hline Total & 0.03 & $(0.02)$ & 0.4 & 0.1 & $(0.03)$ & 2.5 \\
\hline \multirow{2}{*}{\multicolumn{7}{|c|}{$\begin{array}{l}\# 5 \\
\text { Yampa, CO } 1993\end{array}$}} \\
\hline & & & & & & \\
\hline Leaf & 0.2 & $(0.09)$ & 5.6 & 0.6 & $(0.17)$ & 8.3 \\
\hline Bud & 0.0 & $(0.0)$ & 0.0 & 0.06 & $(0.06)$ & 4.5 \\
\hline Flower & 0.0 & $(0.0)$ & 0.0 & 0.0 & $(0.0)$ & 0.0 \\
\hline Total & 0.2 & $(0.09)$ & 5.6 & 0.7 & $(0.18)$ & 8.3 \\
\hline \multicolumn{7}{|c|}{$\begin{array}{l}\# 6 \\
\text { Yampa, CO } 1994\end{array}$} \\
\hline Leaf & 0.0 & $(0.0)$ & 0.0 & 0.0 & $(0.0)$ & 0.0 \\
\hline Bud & 0.0 & $(0.0)$ & 0.0 & 0.0 & $(0.0)$ & 0.0 \\
\hline Flower & 0.0 & $(0.0)$ & 0.0 & 0.0 & $(0.0)$ & 0.0 \\
\hline Total & 0.0 & $(0.0)$ & 0.0 & 0.0 & $(0.0)$ & 0.0 \\
\hline \multicolumn{7}{|l|}{$\# 7$} \\
\hline Salina, UT 1994 & & & & & & \\
\hline Leaf & 0.1 & $(0.02)$ & 1.8 & 0.6 & $(0.14)$ & 2.7 \\
\hline Bud & 0.08 & $(0.03)$ & 0.8 & 0.5 & $(0.2)$ & 2.2 \\
\hline Flower & 0.02 & $(0.01)$ & 0.5 & 1.7 & $(0.5)$ & 4.9 \\
\hline Total & 0.2 & $(0.07)$ & 1.8 & 2.7 & $(0.9)$ & 8.7 \\
\hline \#8 & & & & & & \\
\hline Salina, UT 199 & & & & & & \\
\hline Leaf & 0.07 & $(0.04)$ & 2.9 & 0.9 & $(0.2)$ & 11.8 \\
\hline Bud & 0.0 & $(0.0)$ & 0.0 & 0.0 & $(0.0)$ & 0.0 \\
\hline Flower & 0.02 & $(0.02)$ & 1.9 & 3.2 & $(0.6)$ & 20.2 \\
\hline Total & 0.1 & $(0.1)$ & 4.1 & 4.2 & $(0.7)$ & 21.0 \\
\hline \#9 & & & & & & \\
\hline Montrose, $\mathrm{C}$ & & & & & & \\
\hline Leaf & 0.1 & $(0.005)$ & 0.6 & 0.04 & $(0.02)$ & 0.6 \\
\hline Bud & 0.0 & $(0.0)$ & 0.0 & 0.0 & $(0.0)$ & 0.0 \\
\hline Flower & 0.0 & $(0.0)$ & 0.0 & 0.02 & $(0.01)$ & 0.7 \\
\hline Total & 0.01 & $(0.005)$ & 0.6 & 0.06 & $5(0.03)$ & 0.7 \\
\hline
\end{tabular}

Leaf alkaloid concentration decreased with plant maturity, whereas bud TTA concentrations were initially low, and remained low as tall larkspur flowered (Fig. 1). The ingested toxic alkaloid dose and risk of losing cattle were very low as cattle ate only small amounts of tall larkspur (Table 2) during either the preflower or early flower periods. 

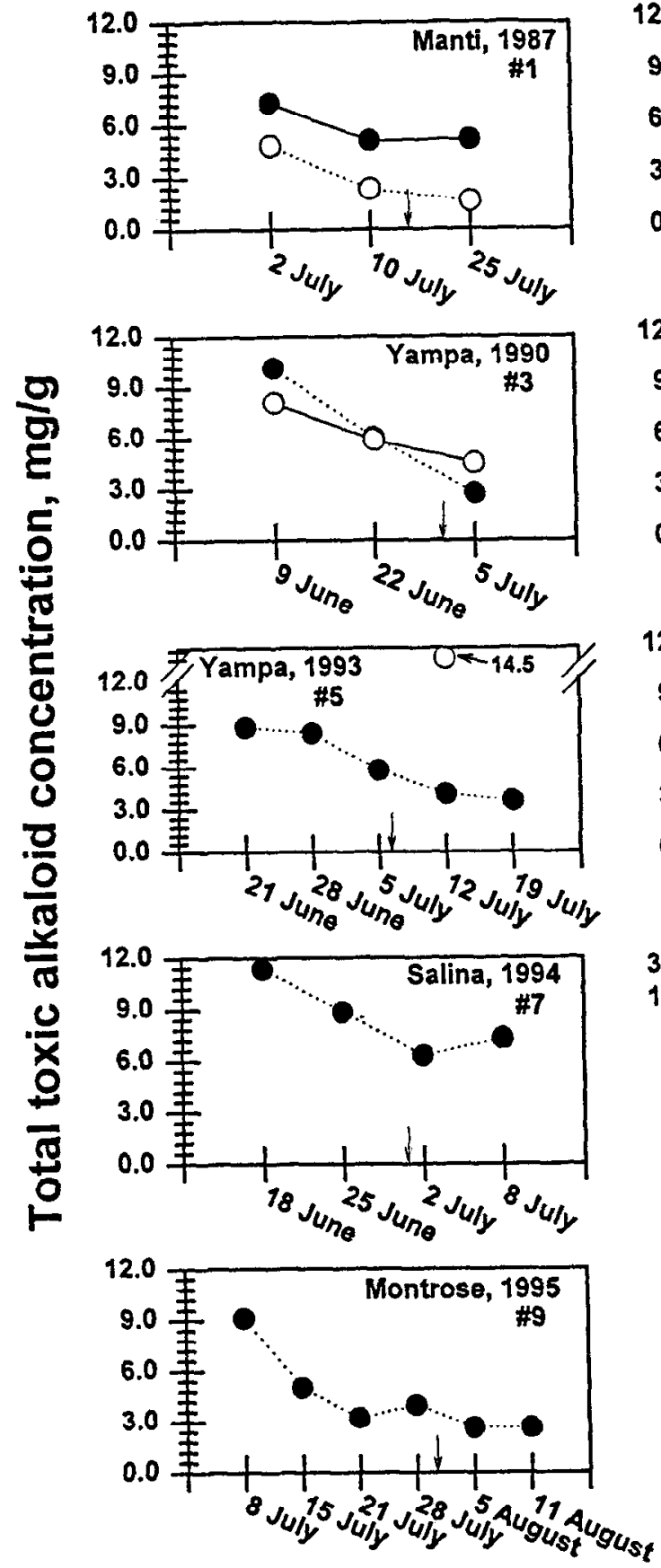
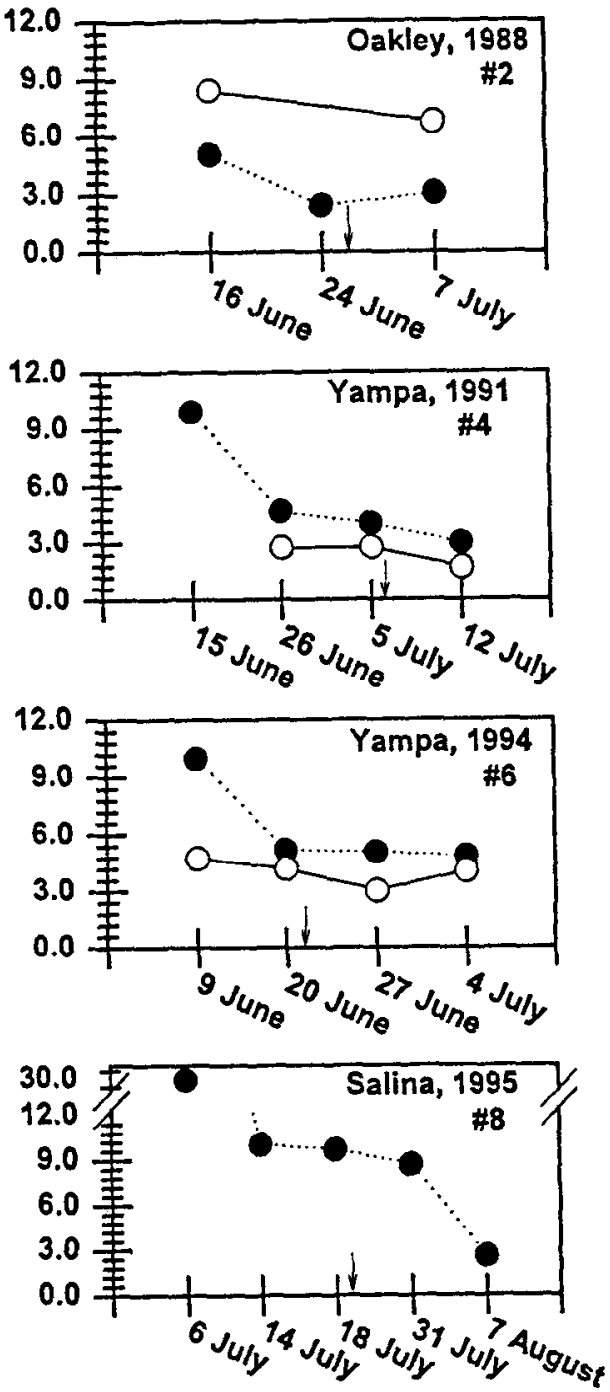

Legend

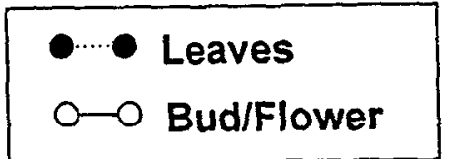

\section{Dates}

Fig. 1. Toxic alkaloid concentration (mg/g, dry wt basis) in tall larkspur leaves and reproductive parts (buds or flowers) during grazing studies conducted in various locations. The number refers to each graxing trial in sequence as detailed in the text, and the arrow shows the approximate date when the early flower period began.

Trial 5. Yampa, Colo. 1993

Cattle ate $<1 \%$ of their bites as larkspur during the 2 periods $(P>0.05)$. During the preflower stage, cattle consumed a few bites of leaves, and during the early flower stage they consumed some leaves and buds (Table 2). Leaves showed a typical decrease in the concentration of TTA with plant maturity. The sole flower sample collected during the early flower stage had a very high TTA concentration (Fig. 1). The dose of toxic alkaloids was very low during the preflower stage because consumption was low; the ingested toxic dose remained low (Fig. 2) on day 17 when 1 cow ate $6 \%$ of her bites as larkspur leaves. During Day 2 of the early flower stage, 1 animal ate $8 \%$ of her bites as 
larkspur leaves, while another animal ate $5 \%$ of her bites as buds on day 4 . The toxic dose would have remained low (Fig. 2) when cattle ate leaves because TTA concentration in leaves was about $4.0 \mathrm{mg} / \mathrm{g}$ (Fig. 1), but the dose was higher when cattle ate substantial amounts of buds because the flower sample collected about this time was very toxic ( $>14 \mathrm{mg} / \mathrm{g}$ ). No clinical signs of intoxication were observed in cattle on that day.

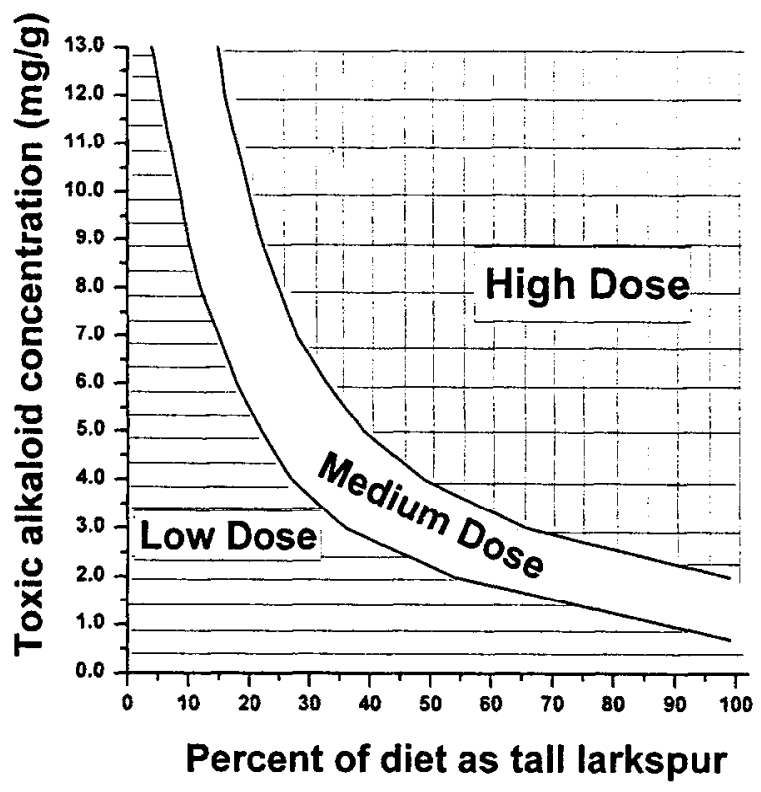

Fig. 2. Dose response of cattle to tall larkspur. The y-axis shows the toxic alkalod (TTA) concentration (mg/g) in tall larkspur and the $x$-axis shows the amount of tall larkspur in cattle diets $(\%$ of dry wt). The risk of poisoning cattle increases as the toxicity of the plant increases and as animal consumption increases.

\section{Trial 6. Yampa, Colo. 1994}

Cattle ate no tall larkspur during the preflower or early flower stages. Concentrations of TTA in leaves showed a characteristic decline early in the preflower stage, but then did not decline thereafter (Fig. 1). Bud and flower concentrations of TTA remained relatively stable over time. The toxic dose, and risk of losing cattle, was essentially zero during both the preflower or early flower stages because of the lack of consumption.

\section{Trial 7. Salina, Utah 1994}

Cattle selected a few bites of tall larkspur leaves during the preflower stage, and increased consumption to about $3 \%$ of bites, primarily flowers, during the early flower stage $(P<0.05$; Table 2). Cattle began consuming a substantial amount of larkspur (average of $5.7 \%$ flowers and $2.1 \%$ leaves) on day 3 of the early flower period, and $1 \mathrm{cow}$ died during the night, presumably from tall larkspur intoxication (or resulting bloat). This cow consumed about $15 \%$ of her total bites as larkspur (mostly flowers) during the late afternoon grazing period; overall her daily larkspur consumption was about $5 \%$. Immature leaves had a high concentration of TTA, and TTA concentration remained relatively high even after tall larkspur began elongating flowering racemes (Fig. 2). The toxic dose was low during the preflower stage because consumption was low (Table 2). During the early flower stage, a fatal dose was ingested by 1 animal; the TTA concentration in leaves on the day previous was about $6 \mathrm{mg} / \mathrm{g}$, but the full toxic dose was unknown as flower samples were not collected. On the other days during the early flower stage, the toxic dose and risk were correspondingly low.

\section{Trial 8. Salina, Utah 1995}

Cattle ate essentially no tall larkspur during most of the preflower stage, but on days 13 and 16 they increased leaf consumption to 1.8 and $0.7 \%$ of bites, respectively (Fig. 3). Cattle averaged $0.1 \%$ of bites as tall larkspur during the preflower stage, compared to $4.2 \%$ during the early flower stage ( $P<0.05$ ); cattle genrally preferred flowers over leaves during the early flower stage (Fig. 3). One cow rapidly ate about $18 \%$ of her diet as larkspur leaves in the late afternoon of day 6 of the early flower stage. She died sometime during the night, presumably from tall larkspur intoxication. Leaves were very toxic early in the grazing season, and retained a relatively high concentration of TTA $>9$ $\mathrm{mg} / \mathrm{g}$ ) into the beginning stages of flowering (Fig. 2). The toxic dose ingested by cattle was low during the preflower stage because consumption was generally low. The toxic dose and risk increased greatly (Fig. 2) when larkspur elongated flowering racemes. Although means were not alarmingly high (Table 2), maximal daily amounts eaten during this period were about 12 and $20 \%$ of bites for leaves and flowers, respectively.

\section{Trial 9. Montrose, Colo. 1995}

Cattle ate a few bites of tall larkspur during both the preflower and early flower stages ( $P>0.05$; Table 2). During the preflower stage, cattle ate a few leaves on 3 different days. During the early flower stage, cattle ate a few leaves on numerous days, but the maximum number of bites taken in a single day by any animal was very low (Table 2). Leaves were relatively consistent in TTA concentrations with values of 2.6 to $5.0 \mathrm{mg} / \mathrm{g}$ during most of the grazing season (Fig.1). The ingested toxic dose was low (Fig. 2) during both the preflower and early flower stages because of low levels of consumption and relatively low plant toxicity.

\section{Discussion}

Cattle generally ate little or no tall larkspur during the preflower stage before larkspur elongated flowering racemes. Therefore, these data strongly support our hypothesis that cattle do not eat tall larkspur before elongation of flowering racemes. Consumption of tall larkspur was also generally low during the early flower stage of growth, except periodically at the 2 Utah sites. These grazing studies indicate that risk of losing cattle to tall larkspur is low if plants have not flowered. Even though concentration of toxic alkaloids is typically high in immature larkspur, cattle are unlikely to eat these plants in sufficient amounts for toxicosis to occur. When tall larkspur does comprise a major portion of an animal's diet, risk of intoxication may still remain low if plant toxicity is low. A good example is the heifer that ate $50 \%$ of her diet as larkspur flowers at Manti, Ut. during 1 day in 1987, yet was not overtly intoxicated because flowers were not very toxic.

It is unclear why tall larkspur growing at the Salina site, and to a lesser extent at Manti, was apparently more palatable to cattle 

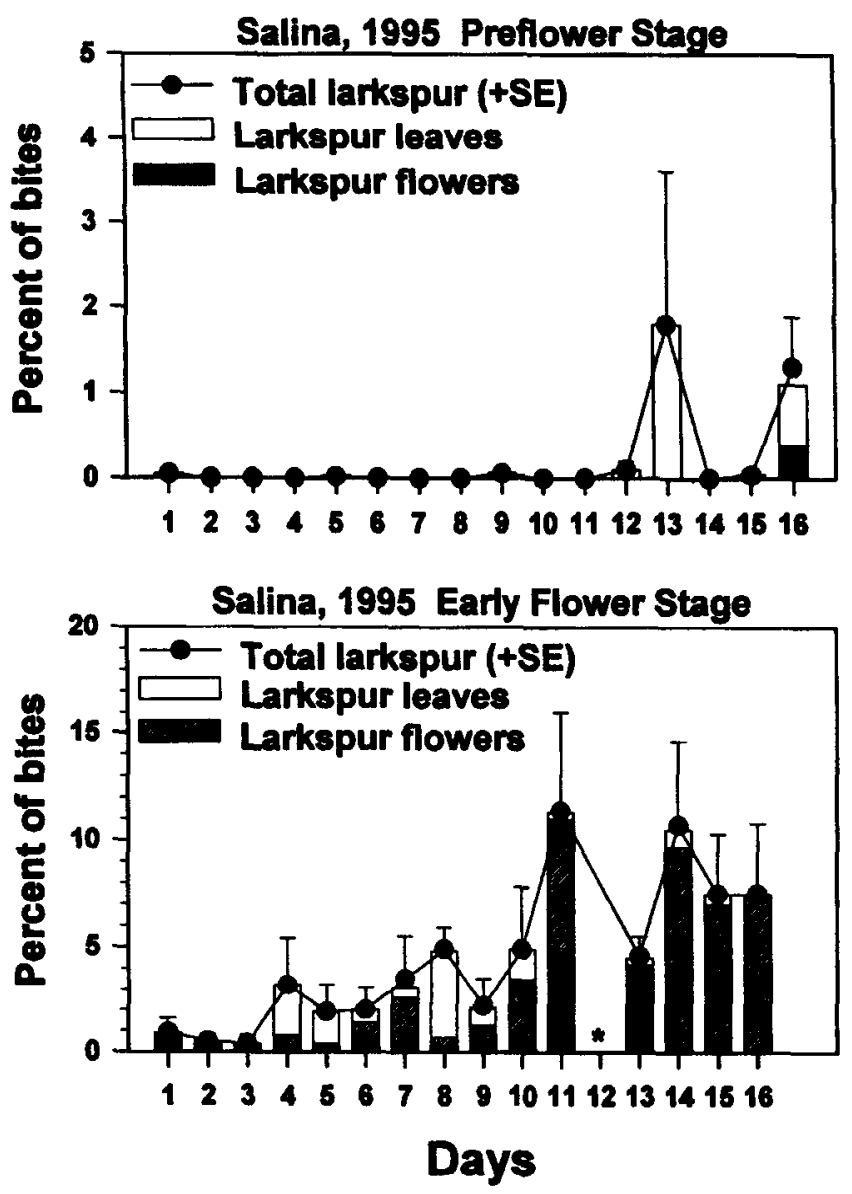

Fig. 3. Consumption of tall larkspur ( $\%$ of bites) by cattle during the preflower (July 6-21) and early flower (2 July-6 Aug.) stages of growth during 1995 in Salina, Ut. (*indicates missing data for that day).

shortly after elongation of flowering racemes in comparison to the other grazing locations. There were 2 fatalities in the grazing studies at Salina when individual cows began eating large amounts of flowers or leaves. In general, cattle ate more flowers at Salina or Manti than at the other sites, and higher flower consumption seems to indicate a higher risk to cattle from more palatable larkspur during the early flower stage. There were not any obvious major differences in leaf toxicity for the Salina population compared to the other sites; unfortunately flowers were not collected at Salina for alkaloid analysis. We have shown that acceptability of tall larkspur to cattle is not influenced by the toxic or total alkaloid concentration (Pfister et al. 1990, Pfister et al. 1996), nor were storms a factor (Ralphs et al. 1994), and we speculate that consumption was driven by other individual plant or plant community factors unrelated to toxicity.

Consumption of tall larkspur leaves and (or) flowers during the early flower stage probably indicates that consumption levels will increase later in the grazing season (Pfister et al. 1988a). On the other hand, lack of consumption during the early flower stage does not necessarily mean that cattle are less likely to eat tall larkspur later in the grazing season (J.A. Pfister, personal observations). Thus, preflower consumption should be used cautiously in attempts to predict postflower consumption. Postflower consumption can begin suddenly and accelerate quickly (Pfister et al. 1988b, Pfister and Manners 1995).
A major consideration in determining risk is the likelihood that cattle will consume a given amount of tall larkspur, as we have previously presented in the context of a toxic window (Pfister et al. 1988a). Our studies have shown that cattle generally ingest low doses of toxic alkaloids before tall larkspur begins flowering. Once tall larkspur elongates flowering racemes, producers are much more likely to lose cattle to tall larkspur poisoning. Actual death losses are influenced by both plant and animal factors. The major animal factor is individual animal susceptibility, whereas major plant factors include concentration of toxic alkaloid and palatability of tall larkspur, which determine dosage and rate of consumption of toxic alkaloids (Pfister et al. 1988b).

If consumption is low or nil, then risk of losing cattle will also be low regardless of toxic alkaloid concentration. As cattle begin to consume increasing amounts of tall larkspur, toxic alkaloid concentration becomes critical in making grazing management decisions. In particular, consumption of flowers during the early or full flower period should warn of potential high risk situations. For a crude indication of tall larkspur consumption, livestock producers can quickly note defoliation of flowers (perhaps even leaves) without seeing cattle actually eat tall larkspur. Figure 2 can provide general guidelines to help producers determine the toxic alkaloid dose that animals may ingest. Grazing management decisions can be improved if information on plant toxicity and possible dose response is considered along with the probability that cattle will eat injurious amounts of tall larkspur at a particular phenological stage (i.e., toxic window).

Although we have not studied the ecological consequences of early grazing, grazing early followed by a rest period is probably benign or even beneficial for other forbs and perennial grasses (Richards and Caldwell 1985, Lacey et al. 1994), and thus is unlikely to increase larkspur populations. If cattle numbers are reduced after flowering, decreased grazing pressure on tall larkspur may increase larkspur density over long periods of time (e.g., 40 years, Ellison 1954). On the other hand, flowering tall larkspurs are probably important vectors for hummingbird and bee populations (Inouye et al. 1991, Inouye and McGuire 1991), and reducing cattle grazing during flowering may benefit livestock producers by reducing cattle deaths while benefitting other organisms.

\section{Management Implications}

Much of the productive forage on tall-larkspur infested rangeland is underutilized because cattle grazing is deferred or curtailed due to perceived risk of cattle deaths caused by tall larkspur. Our studies indicate that many livestock operations can typically gain 4 to 5 weeks of grazing on these infested ranges early in the grazing season. Since cattle can graze tall larkspur-infested ranges before elongation of flowering racemes with little risk of death losses from tall larkspur toxicosis, management of tall larkspur-infested rangeland should be evaluated to determine if it is feasible to take advantage of this low-risk period. When feasible within a multiple use setting, cattle should be grazed on these ranges as soon as sufficient forage is available; livestock producers should also consider removing cattle or reducing cattle numbers when tall larkspur flowers. The transition in tall larkspur phenology from the preflower to flowering state can be easily distinguished by simply noting whether the majority of racemes 
have elongated. Fully developed tall larkspur buds often "nod" or droop to one side when raceme elongation begins, and this is another visual clue that the transition is occurring. If cattle remain on tall-larkspur infested rangeland after plants have flowered, and cattle eat significant quantities of tall larkspur, relative risk of losing cattle may be high until tall larkspur toxicity declines with maturation. Our results do not apply to low larkspurs (e.g., $D$. nuttallianum) or to plains larkspur (D. geyeri) as specific grazing recommendations have not been developed for these species.

\section{Literature Cited}

Altmann, J. 1974. Observational study of behavior: sampling methods. Behav. 49:227-265.

Cordova, F.J., J.D. Wallace, and R.D. Pieper. 1978. Forage intake by grazing livestock: a review. J. Range Manage. 31:430-438.

Drasdo, A., M. Caulfield, D. Bertrand, S. Bertrand, and S. Wonnacott. 1992. Methyllycaconitine: a novel nicotinic antagonist. Molecul. Cell. Neurosci. 3:237-243.

Ellison, L. 1954. Subalpine vegetation of the Wasatch Plateau, Utah. Ecol. Monogr. 24:89-184.

Inouye, D.W. and A.D. McGuire. 1991. Effects of snowpack on the timing and abundance of flowering in Delphinium nelsonii: implications for climate change. Amer. J. Bot. 78:997-1001.

Inouye, D.W., W.A. Calder, and N.M. Wasser. 1991. Estimates of hummingbird population size as a function of flower abundance. Condor 93:279-285.

Lacey, J., S. Studiner, and R. Hecker. 1994. Early spring grazing on native range. Rangelands. 16:231-233.

Manners, G.D. and J.A. Pfister. 1993. Normal phase liquid chromatographic analysis of toxic norditerpenoid alkaloids. Phytochem. Anal. 4:14-18.

Manners, G.D. and J.A. Pfister. 1996. Sampling a poisonous plant population: quantifying toxic alkaloids in tall larkspur (Delphinium barbeyi) leaves. Weed Sci. 44:782-788.

Manners, G.D., K.E. Panter, and S.W. Pelletier. 1995. Structure-activity relationships of norditerpenoid alkaloids occurring in toxic larkspur (Delphinium) species. J. Nat. Prod. 58:863-869.

Manners, G.D., K.E. Panter, M.H. Ralphs, J.A. Pfister, and J.D. Olsen. 1993. The occurrence and toxic evaluation of norditerpenoid alkaloids in the tall larkspurs (Delphinium sp.). J. Food Agr. Chem. 41:96-100.

Nielsen, D.B. and M.H. Ralphs. 1988. Larkspur: economic considerations. p. 119-130. In: L.F. James, M.H. Ralphs, and D.B. Nielsen (eds.). The ecology and economic impact of poisonous plants on livestock production. Westview Press, Boulder, Colo.

Pfister, J.A. and G.D. Manners. 1991. Mineral supplementation of cattle grazing larkspur-infested rangeland during drought. J. Range Manage. 44:105-111.

Pfister, J.A. and G.D. Manners. 1995. Effects of carbachol administration in cattle grazing tall larkspur-infested range. J. Range Manage. 48:343-349.

Pfister, J.A, K.E. Panter, and G.D. Manners. 1994b. Effective dose in cattle of toxic alkaloids from tall larkspur (Delphinium barbeyi). Vet. Human Toxic. 36:511-514.

Pfister, J.A., F.D. Provenza, and G.D. Manners. 1990. Ingestion of tall larkspur by cattle: separating effects of flavor from postingestive consequences. J. Chem. Ecol. 16:1697-1705.

Pfister, J.A., M.H. Ralphs, and G.D. Manners. 1988b. Cattle grazing tall larkspur on Utah mountain rangelands. J. Range Manage. 41:118-122.

Pfister, J.A, G.D. Manners, D.R.Gardner, and M.H. Ralphs. 1994a. Toxic alkaloid levels in tall larkspur (Delphinium barbeyi) in western Colorado. J. Range Manage. 47:355-358.

Pfister, J.A., F.D. Provenza, G.D. Manners, D.R Gardner, and M.H. Ralphs. 1997. Tall larkspur ingestion: can cattle regulate intake below toxic levels? J. Chem. Ecol. 23:759-777.
Pfister, J.A, G.D. Manners, D.R. Gardner, K.W. Price, and M.H. Ralphs. 1996. Influence of alkaloid concentration on acceptability of tall larkspur (Delphinium spp.) to cattle and sheep. J. Chem Ecol. 22:1147-1168.

Pfister, J.A., G.D. Manners, M.H. Ralphs, Z.X. Hong, and M.A. Lane. 1988a. Effects of phenology, site and rumen fill on tall larkspur consumption by cattle. J. Range Manage. 41:509-514.

Ralphs, M.H., J.D. Olsen, J.A. Pfister, and G.D. Manners. 1988. Plant-animal interactions in larkspur poisoning in cattle. J. Anim. Sci. 66:2334-2342.

Ralphs, M.H., D.T. Jensen, J.A. Pfister, D.B. Nielsen, and L.F. James. 1994. Storms influence cattle to graze larkspur: an observation. J. Range Manage. 47:275-278.

Richards, J.H. and M.M. Caldwell. 1985. Soluble carbohydrates, concurrent phototsynthesis and efficiency regrowth following defoliation: a field study with Agropyron species. J. Appl. Ecol. 22:907-920.

SAS. 1988. SAS User's Guide SAS/STAT (Release 6.03). SAS Inst. Inc., Cary, N.C. 